\title{
NECROECOTEOLOGÍA. HERMENÉUTICA CONTRAHEGEMÓNICA EN TIEMPOS DE PANDEMIA
}

Necroecotheology. Counter-hegemonic hermeneutics in times of pandemic

Necroecoteologia. Hermenêutica contra-hegemônica em tempos de pandemia

José Octavio Toledo Alcalde ${ }^{1}$

\begin{abstract}
Resumen
El presente artículo se aproxima al tema de los fines depredadores de la instrumentalización, colonial y neocolonial, de la fe con base cristiana, la antropología, la ecología, y la política. Se propone el neologismo necroecoteología y la subjetividad instrumental como llaves de interpretación transdisciplinarias del desequilibrio humano-ambiental, sobre todo en tiempos de crisis planetaria como la que nos impone la pandemia. De igual forma, se muestra el punto de inflexión entre la secularidad europea y la subjetividad religiosa colonial impuesta en tierras invadidas. Desde trabajos de activistas de la teología y filosofía de la liberación, derechos humanos, y disciplinas afines, se vincula teología, política y ecología en una misma plataforma de análisis, discusión y propuestas de alternativas resolutivas. Se concluye con una de estas propuestas, otro neologismo, la ecosacralidad, una visión contrahegemónica más allá del mundo cristiano, que busca re-eequilibrar y re-unir la relación humano-ambiental.
\end{abstract}

Palabras claves: Ecoteología, sacralidad, colonialidad, racionalismo, subjetividad.

\begin{abstract}
This article approaches the theme of the predatory aims of colonial and neocolonial instrumentalization of christian faith, anthropology, ecology, and politics. This work proposes the neologism necroecotheology and instrumental subjectivity as keys of
\end{abstract}

1 José Octavio Toledo Alcalde es peruano-italiano. Licenciado en Teología por la Universidad Bíblica Latinoamericana, Costa Rica. Posgrado en Cultura de la Paz, Cohesión Social y Diálogo Intercultural: Aplicaciones Prácticas por la Universidad de Barcelona, la Fundación Carta de Paz dirigida a las Naciones Unidas y el Instituto de Formación Continua-IL3. Estudiante de maestría en Derechos Humanos y Educación para la Paz en el Instituto de Estudios Latinoamericanos (IDELA) de la Universidad Nacional, Costa Rica. Activista de derechos humanos a favor de colectivos de inmigrantes, actuando en producción de documentales, acompañamiento y artículos de opinión en plataformas de Latinoamérica y el Caribe. Colabora con la Iglesia Evangélica Española. Email: joctavio9@gmail.com. ORCID: https://orcid.org/ my-orcid?orcid=0000-0002-9331-349X 
transdisciplinary interpretation of the human-environmental imbalance, above all in times of planetary crisis such as that which the pandemic imposes on us. In the same way, it shows the inflection point between European secularism and colonial religious subjectivity imposed in invaded lands. Using the works of activists of liberation theology and philosophy, human rights, and related disciplines, the article connects theology, politics and ecology in one platform of analysis, discussion, and proposals of resolute alternatives. The piece concludes with one of these proposals, another neologism, ecosacrality, a counter-hegemonic vision from beyond the christian world, that seeks to re-balance and re-unite the human-environmental relationship.

Keywords: Ecotheology, sacrality, coloniality, rationalism, subjectivity.

\section{Resumo}

O presente artigo se aproxima ao tema dos fins depredadores da instrumentalização, colonial e neocolonial, da fé com base cristã, a antropologia, a ecologia, e a política. São propostos o neologismo necroecoteologia e a subjetividade instrumental como chaves de interpretação transdisciplinares do desequilíbrio humano-ambiental, sobretudo em tempos de crise planetária como a que nos impõe a pandemia. De igual forma, mostra-se o ponto de inflexão entre a secularidade europeia e a subjetividade religiosa colonial imposta em terras invadidas. A partir de trabalhos de ativistas da teologia e filosofia da libertação, direitos humanos, e disciplinas afins, vinculamse teologia, política e ecologia em uma mesma plataforma de análise, discussão e propostas de alternativas resolutivas. Conclui-se com uma destas propostas, outro neologismo, a ecossacralidade, uma visão contra-hegemônica além do mundo cristão, que busca re-equilibrar e re-unir a relação humano-ambiental.

Palavras chaves: Ecoteologia, sacralidade, colonialidade, racionalismo, subjetividade

\section{Introducción}

Fe y razón, subjetivación y racionalización, instrumentos de opresión o liberación, de vida o muerte. En esta oportunidad traemos tres variables de reflexión unidas en la historia como parte de programas de control colonial y neocolonial, los cuales, en contexto de pandemia, han adquirido relevancia en medio de una de las más espeluznantes y terroríficas experiencias de la humanidad de los últimos años, sin dejar de lado admitir que existen pueblos que históricamente se encuentran en situaciones de empobrecimiento y miseria quizá de mayor intensidad que la ocasionada por la pandemia. La teología, la ecología y la sanidad marcan el historial de invasiones de control geopolítico y económico de América Latina y el Caribe desde el siglo XV hasta nuestros días sin descanso alguno. Será desde la necroecoteología, como clave hermenéutica propuesta en el presente artículo, que abordaremos las tres variables aludidas, todo esto desde una visión crítica contrahegemónica desde una lectura del Sur Global. 
Problemas relacionados con la crisis por la cual atraviesa toda expresión de vida, como consecuencia del histórico desequilibrio ambiental, social y sanitario, han sido y siguen siendo abordados por especialistas en la materia de forma exhaustiva. Desde nuestra no especializada participación en las materias citadas, proponemos, como objetivo del presente artículo, incidir con reflexiones ya realizadas, sobre el aspecto y relevancia política de tres variables: teológico, ecológico y sanitario, desde la perspectiva de su instrumentalización como herramientas de dominio, control y enajenación. Variables invisibilizadas, como regla generalizada, del discurso, discusión y debate político, que excluyen su participación del escenario de contribuciones de teorías del conocimiento orientadas a la búsqueda del bien común de los pueblos.

Es decir, nuestra idea es reflexionar sobre diferentes variables históricas y epistemológicas en torno, no a discusiones técnicas o doctrinales sobre las luchas por el cambio climático o los orígenes simbólicos de la creación sino, sobre la estructura ideológica, religiosa y política, que subyace históricamente en la catástrofe global en la cual se encuentra sumergida la humanidad y toda forma de vida.

La historia nos demuestra que es a través de estas tres variables -teología, ecología y sanidad- por medio de las cuales se justificaron, y siguen justificándose, modelos de control de cuerpos, territorios y espacios. Mecanismos coloniales y neocoloniales, de control y exterminio desde los cuales matrices de opinión y programas de gobernabilidad, ya sea en el siglo XV como en el siglo XXI, ejecutan programas de exclusión social sin ningún tipo de censura vinculante del orden jurídico regional e internacional. Más aún, estas tres variables instrumentalizadas, del pensamiento único, como diría Ignacio Ramonet, han contado con la legitimización de facto de una jurisprudencia del derecho internacional muchas veces cómplice de graves indicios de incoherencias del derecho.

Entonces, en este contexto de perpetuidad y metamórfica adaptación y readaptación de matrices de control global y regional, nos preguntamos: ¿Por qué hablar de necroecoteología, como expresión de violencia generalizada, en mundos, occidentales y occidentalizados, cada vez más secularizados (tecnologizados) y democráticos (aburguesados)?

$\mathrm{Si}$ bien es cierto, la secularización fue el signo incuestionable del cambio de paradigma, desde una visión eurocéntrica, pragmática, mecanicista, no podemos sostener lo mismo desde la perspectiva del desarrollo histórico de los pueblos colonizados 
de Latinoamérica y el Caribe, quienes vivieron procesos históricos, sociales, culturales y epistémicos, diferentes a los vividos en otras latitudes, como signo incuestionable del paradigma del desarrollo desigual que aborda Boaventura de Sousa Santos (2003). El cogito cartesiano colonial llegó a tierras invadidas con unidades de medida de la comprobación de realidades visibles e invisibles mediatizada por subjetividades $u$ objetividades diametralmente diferentes, y antagónicas, a las de las culturas originarias. El método colonialista cartesiano, de construcción de saberes, separó el mundo de los sentidos del yo pensante-conquistador (ego cogito), de la razón matriz de la ciencia moderna.

La necroecoteología, vale decir, la instrumentalización colonialista de fe-razón y naturaleza-ser humano, con fines de control y dominio, solo puede ser posible en la "... percepción de la realidad desde un punto de vista distinto al de los sentidos ... (Flórez, 2011, p. LXVIII). La percepción antropológica de la necroecoteología es, por principio, cartesiana. Perspectiva mecanicista donde el ser humano "deja ser concebido como un continente capaz de ser habitado por Dios y divinizado y pasa a ser concebido como una potencia (naturaleza humana) (Flórez, 2011, p. C). El proyecto depredador del siglo XV tenía claro que las tierras por poseer y seres humanos por esclavizar no eran seres autónomos sino realidades objetivas (realitas objective), dispuestas a ser dominadas bajo el imperio de la razón por el verdadero sujeto (subjectum), el ser conquistador (Marquínez, 2002, p.52). El mito de la creación y la orden divina de fecundar, multiplicar y dominar la tierra fue encajada a la perfección en una visión que releyó, interpretó y contextualizó el mito sin error alguno.

La historia de genocidios y ecocidio, por medio de la razón instrumental, en búsqueda de autonomía, adultez racional y control geopolítico es segregacionista y depredadora por la naturaleza aristotélica y cartesiana de su fundamentación. Controlar cuerpos (sobre todo de mujeres) y territorios es la ecuación perfecta, oleada y sacramentada, a la luz del derecho canónico y romano. Dualismos como: amos/ siervos, cristianos/paganos, salvos/ perdidos, cielos/infiernos, abstracto/ concreto, espíritu/cuerpo, sujeto/objeto, ideal/real, son binomios sexistas en donde el prime polo es considerado dominante, por ende, masculino. Como enfatiza Santos, "si el organismo es la forma tecnocientífica del cuerpo, el organismo de la mujer es la forma tecnocientífica de colocarla en el polo dominado de cualquiera de los dualismos referidos (la naturaleza, lo concreto, el objeto, lo real)" (Santos, 2003, p. 97).

Los parámetros de la delimitación necroecotelógica se encuentran 
delimitados por dos escenarios: la racionalidad instrumental (dominador de la naturaleza y ser humano) y de aquello que estamos denominando subjetividad instrumental (dominado por la naturaleza y el ser humano): "la historia de los esfuerzos del hombre destinados a subyugar la naturaleza es también la historia del sojuzgamiento del hombre por el hombre" (Horkheimer, 1969, p. 115). La subjetividad instrumental subsumida por el imperio de la razón instrumental es el sutil elemento para considerar desde una praxis liberadora por la trilogía del sujeto liberador de Hinkelammert (1984): "sujeto vivo, intersubjetivo y práxico" (Rosillo, 2016, p. 740). El sujeto necroecoteológico es el sujeto objetivado, fragmentado, individualizado, disociado de sí y su entorno; sin intersubjetividad. instrumentalizado, legitimador del orden establecido: “... el orden social objetivado ya lleva implícito una legitimidad ..." (Hinkelammert, 1984, p. 35).

La trama histórica del presente artículo pretende ir más allá de la aparición histórica de la racionalidad instrumental como punto de partida de la modernidad, con la subsiguiente instrumentalización de las relaciones de producción, ecológicas y sociales. La necroecoteología parte de una lectura histórica que data de narraciones míticas, como la judeocristiana, las cuales, instrumentalizando subjetividades religiosas y espirituales, de comunidades y pueblo originarios, subyugaron corporeidades y territorialidades no solo como signo de poder sino como señal incuestionable de cambio e implantación de un único modelo de existencia asumido por los poderes hegemónicos e impuestos a pueblos colonizados (Cf. Foucault, 2007).

La necroecoteología tiene como punto de partida imaginarios y cosmovisiones colectivas no secularizadas, en sus orígenes, las cuales transitaron caminos de secularización (racionalidad objetiva) para ser dirigidos finalmente hacia escenarios no secularizados (zonas de invasión) donde encontró su perfecta justificación por medio de la subjetividad instrumental estética y religiosa. Como referencia de uno de los orígenes fundantes del sentir colonial tenemos la base mítica judeocristiana del Génesis. El mandato mítico del libro de Génesis sobre el control, dominio y señorío del ser humano, sobre todo lo existente, parte de principios estéticos y metafísicos con dosis de racionalidad subjetiva. Principios morales y éticos, los cuales lograron sentar las bases de una racionalidad lógico-instrumental y de una epistemología dualista (sociedad/naturaleza), sexista y antropocéntrica con un innegable componente de religiosidad instrumentalizada, fundamento de toda praxis epistemicida. 
La conquista espiritual, de la cual nos habla Dussel, se abrió paso como un magno evento evangelizador, una cruzada espiritual de valores invertidos del reino de Dios profesados en las tradiciones evangélicas. La empresa colonial genocida, etnocida, xenofóbica, ecocida, se dio como un proyecto unitario, racional y subjetivo, solventado como método de injerencia hasta nuestros días. "Con o sin conciencia, la Iglesia se articula con el poder conquistador ... La «clase» conquistadora, encomendera, comerciante, insignificante por su número, se presenta ante el indio siendo una con los misioneros y clérigos" (Dussel, 1983a, p. 708).

Es así como para la necroecoteología es la cristiandad, y no el cristianismo, la base ideológica-doctrinal sobre la cual se tejieron la fundamentalista versión religiosa del proyecto expansivo más sanguinario de los últimos seiscientos años. De allí que toda expresión de cristianismo, ya sea en el siglo XV como en el siglo XXI, que cuestionara las bases dominantes de la cristiandad, haya sido perseguida, anatemizada, excomulgada y relegada al olvido. Por ejemplo, como lo recuerda Dussel, en el caso de los jesuitas echados de América en 1767, la actitud crítica de esta orden religiosa que asumieron ante la corona española les costó la legitimidad institucional:
... las misiones jesuíticas eran verdaderos estados dentro del estado hispánico y esto tampoco podía admitirlo el absolutismo borbónico. De tal manera que cuando la iglesia cobra autonomía se la expulse y cuando admite formar parte de esta totalidad cultural entonces hay paz ... en ese caso la iglesia ha perdido el impulse profético y crítico propio del cristianismo (Dussel, 1978, p. 54).

Lejos de discutir si estamos o no de acuerdo con Dussel, quien sostiene que el proyecto colonizador podría haber sido "con o sin conciencia" o "irracional", nuestra reflexión tratará de releer y reinterpretar la historia desde el reverso antagónico de una ecoteología, o ecosacralidad de la cual hablaremos más adelante, de base racional creativa, histórica, versus una ecoteología racional instrumental. Por ello hacemos eco de la invocación de Leonardo Boff, por entender la cuestión ecológica como el ingreso a un nuevo nivel de la conciencia mundial, la hacemos nuestra y desde allí especulamos y meditamos.

Boff (2000) nos recuerda la importancia de la tierra como el destino común de la naturaleza y del ser humano desde una visión interdependiente y ante el riesgo apocalíptico que sufre la creación. Destino común de la naturaleza caracterizado por el encuentro, y no lo contrario, entre culturas, en donde la 
otredad se construye desde los imaginarios de respeto y convivencialidad creativa, política, económica, espiritual, lo cual no existió en las invasiones europeas del siglo XV y anglo-europeas del siglo XXI. De allí que el elemento necroecoteológico subrepticiamente forma parte intrínseca de las matrices de expansión geopolítica sin que sea una variable colonizadora evidente o tangible como son las explicitas: militar, mediática, diplomática y jurídica.

Por otro lado, contamos con la confirmación de que la persistencia y recrudecimiento de los programas de desencuentro neocolonizador, antes que doblegar el espíritu emancipador de los pueblos, lo acrecienta. Para quienes gozan de la ventaja del elemento crítico en el análisis este les da la posibilidad de leer diacrónica y sincrónicamente la complejidad de un presente neocolonizado a la luz de un colonizado pasado aún existente. Otrora se exterminaba en nombre de la iglesia, Cristo, el papa y los reyes, hoy se aniquila en nombre de la democracia, el imperio de la ley, el Estado de derecho, los universales derechos humanos, el desarrollo sostenible, la interculturalidad y la paz.

De la misma forma que existieron bulas papales y decretos reales que justificaron todo tipo de arbitrariedad y despotismo colonial, hoy en nombre de la Declaratoria Universal de los Derechos Humanos, del Derecho Internacional, de la Carta Democrática Interamericana, de la lucha contra la pobreza, pero nunca contra la riqueza, se violan soberanías de los pueblos del Sur Global y planifican matrices de desestabilización de gobiernos contrarios al eje necrocolonizador planetario.

En este escenario hegemónico de inmunidades, sobre todo la jurídica, la matriz violenta y terrorífica reemplazaron el elemento estético y religioso del imaginario reflexivo y analítico. Artimaña de manipulación de masas construidas so pretexto de una autonomía y adultez de una era que nunca logró salir de las taras desequilibradas de una personalidad colectiva destruida por el deseo individualista y corporativo del poder sin límites.

En este complejo y no irracional escenario, los cálculos abundan en ejemplos; la necroecoteología se fundamenta en un sistema judicial hegemónico sacrificial (venganza) entendido como violencia legal y santa, frente a una violencia ilegal y pagana atribuida a toda expresión contrahegemónica. Persecuciones jurídicas, o la criminalización de la praxis política y teológica contrahegemónica, en pleno siglo XXI, reemplazan encubiertamente prácticas como la del Santo Oficio, en donde la metodología fundamentalista basada en ritos sacrificiales y los chivos expiatorios vienen a ser, en 
esencia, exactamente los mismos del siglo $\mathrm{XV}$.

En palabras de Girard:

De igual manera que las víctimas sacrificiales son ofrecidas, en principio, a la complacida divinidad, el sistema judicial se refiere a una teología que garantiza la verdad de su justicia. Esta teología puede llegar a desaparecer, como ha desaparecido en nuestro mundo, y la trascendencia del sistema permanece intacta. Pasan siglos antes de que los hombres se den cuenta de que no hay diferencia entre su principio de justicia y el principio de la venganza (Girard, 1995, p. 30-31).

Tal cual sucedió en el siglo XV, con las primeras jaurías invasoras provenientes de Europa, y posteriormente del norte de América, sedientas de sangre y hambrientas de oro, prestas a quebrar sistemas originarios de convivencia, cultura, espiritualidad, tecnología, cientificidad, arte, agropecuaria, etc., lo mismo sucede ya entrados en el segundo decenio del siglo XXI. Como otrora existieron ejes del poder civil y eclesiástico que normaron escalas de principios y valores a su justa medida, hoy por hoy los ejes de control y dominio global norman e institucionalizan injerencias (p.e. medidas coercitivas y unilaterales) y exterminios sistémicos en nombre del desarrollo integral y sostenible, del crecimiento económico con equidad, protección del medio ambiente, de cohesiones sociales y consolidación de la democracia.

Como Hinkelammert, quien señaló que la cristiandad conquistó la tierra porque la tierra es de Dios y el imperio su herramienta, en la actualidad programas de control unilateral, como las mencionadas líneas arriba, lo hacen en nombre de Dios, la libertad, el desarrollo y los derechos humanos. Al mismo tiempo se gestan invasiones y confiscan recursos para la obtención última de planes de control terroríficos $\mathrm{y}$ absolutos de cuerpos, territorios y espacios. En palabras de Hinkelammert (1998a): "Violar el derecho a la inviolabilidad del cuerpo se trasforma en el mismo acto de expropiación de un terreno en nombre de la utilidad pública, cuando se decide pone en este lugar una carretera" (p. 26). Esta instrumentalización de la fe, en nombre de la civilidad, redención y lealtad a la corona, ingresó de mano de una modernidad montada a caballo: “... la cristiandad es un cristianismo que es del mundo, Jesús como Cristo monta a Caballo, y se despide del asno. Detesta ahora al Jesús que se monta en un asno" (Hinkelammert, 1998a, p. 208).

En nombre de todos estos nobles proyectos liberales se consolida la necroecoteología como práctica de fe, obediencia del mandato de dominio de la naturaleza y consolidación del derecho natural que no entiende de 
derechos humanos, menos de derechos de la naturaleza: “... para el posicionamiento del derecho natural antiguo no existen derechos humanos, entendido como capacidades subjetivas, sino obligaciones o deberes. Y para el derecho natural moderno, derechos humanos no se vincula con relaciones sociales, sino que se predica solo de caracteres de individuos estancos" (Gallardo, 2010, p. 60).

Teología del imperio del terror, de rodillas en los templos del gran ídolo, la idolatría del todopoderoso Capital, actuando sobre la miseria humana y ambiental. En suma, el fetiche de Marx. De allí que la urgencia del presente artículo radica en el imperativo de articular racionalidades y subjetividades emancipadoras que coloquen en evidencia el proyecto necrocolonizador, en donde las arquitecturas de control y dominio expansivo siguen valiéndose de variables tanáticas inseparables como a las que se ha reducido la teología, la ecología y la política.

Por decirlo sumariamente, en un primer momento abordaremos la conceptualización de la necroecoteología. En un segundo momento desarrollaremos propuestas de claves hermenéuticas desde el enfoque necroecoteológico y, a partir de allí, para en un tercer momento desentrañar la variable necroecoteológica desde reflexiones $\mathrm{y}$ análisis provenientes del fetiche de
Marx. En la cuarta parte veremos la necroteología a la luz del homo æeconomicus. Será como quinto punto donde abordaremos la relación entre necroteología y cultura del terror. En el sexto punto desarrollaremos la subjetividad instrumental colonizadora desplazada del análisis crítico. Finalizaremos, en un séptimo momento, con la necroecoteología, la ecoteología, la ecosacralidad y la urgencia de visibilidad de las construcciones teóricas existentes sobre las cueles se basan las estructuras de pensamiento y las practicas cotidianas legitimadoras de cruentas estructuras de poder erguidas contra toda expresión de vida sobre la faz de la tierra.

\section{Necroecoteología}

Racionalizar, planificar y ejecutar programas de exterminio humano-ambiental en nombre del monoteísmo y Estado absoluto, sea cual fuere su naturaleza religiosa e ideológica, o en nombre de universalizados criterios de paz y seguridad internacional es necroecoteología. Macabra práctica global de exterminio humano-ambiental que, desde la racionalidad instrumental, construyó matrices hegemónicas de control de cuerpos y territorios tal cual fueron sometidos desde el oscuro Medioevo, religiosamente militarizado, hasta la transmodernidad tecnologizada y militarizada del siglo XXI. 
Ahora, desde una visión de las epistemologías del Sur Global, para Boff, la ecología, más allá de la comprensión biológica y científica del creador del término ecología Ernst Haeckel (1834-1919), es la ciencia y arte de las relaciones y de los seres relacionados. "La casa-habitad oikos ... está hecha de seres vivos, materia, energía, cuerpos y fuerzas en permanente relación. En esta perspectiva ... la ecología posee un contenido eminentemente teológico" (Boff, 2000, p. 23).

... es relación, interacción y diálogo de todas las cosas existentes (vivientes o no) entre sí y con todo lo que existe, real o potencial ... no tiene que ver solo con la naturaleza (ecología natural), sino principalmente con la sociedad y con la cultura (ecología humana, social, etc.). ... La cuestión ecológica remite a un nuevo nivel de la conciencia mundial: la importancia de la tierra como un todo, el bien común como bien de las personas, de las sociedades y del conjunto de los seres de la naturaleza ... (Boff, 2000, p. 18-20).

Visión holística de Boff, ajena a la filosofía tanática de la necroecoteología. Perspectiva pragmática y fragmentada de los cuerpos separados entre sí y su entorno; en donde la vida no cuenta con más valor que el utilitarista. Valemos mientras producimos, fuera de ello debemos considerarnos "material descartable". Así como tierras explotadas a "cielo abierto" son desangradas hasta más no poder, siendo inhabilitadas por siempre, así es el periodo de la ancianidad, destrozada a "infierno abierto"; personas inhabilitas por el resto de sus vidas. La centralidad egoísta del ego cogito destruyó todo signo de una ética de la convivencialidad (Illich, 1975). Todo esto, sin posibilidad para intersubjetividades entre cuerpos y territorios en el marco de una sincronicidad holística, armoniosa, restitutiva y reparadora, de cara a una diacronicidad fragmentaria, instrumentalizadora, acrítica, tecnócrata, futurista.

A este punto, desde la perspectiva teológica, cuando a la luz de las reflexiones de Tomas de Aquino, Gustavo Gutiérrez (1975) habló, entre otras consideraciones, del quehacer teológico como saber racional resaltando la presencia de materias como las ciencias sociales, las psicológicas y las biológicas, más allá del saber filosófico. Esta percepción sigue siendo la característica principal del quehacer teológico sentida, racionalizada y ejecutada desde las comunidades del Sur Global, y sobre esta base se ha desarrollado el peregrinaje profético y utópico de las comunidades de fe abiertas a las novedades de modelos de convivencia que optan por una praxis ecoteológica de cara a la construcción de imaginarios de alteridad sostenible entre seres y naturaleza (Ellacuría, 1990). 
La matriz religiosa instrumental, preñada de cientificidad especulativa, hace de la teología, entendida por Gutiérrez como inteligencia de la fe, praxis histórica, espiritual y saber racional, el conjunto de lineamientos pragmáticos orientados a la negación de las características antes mencionadas (Gutiérrez, 1975). Para Richard y Torres (1975), la percepción del quehacer teológico, según Gutiérrez, es entendida como una reflexión crítica de la praxis histórica a la luz de la fe. Todo lo contrario, desde una dramática inversión de valores, la necroecoteología es el conjunto de razonamientos y prácticas de índole acrítica, pragmática y ahistórica realizada a la luz del mercado, el fetiche de Marx del cual hablaremos más adelante.

Como un breve ejemplo de una perspectiva teológica de la liberación poco recurrida en los análisis, como reflejo opuesto de la necroecoteología, y ecosacralidad, es aquella que se expresa desde la experiencia de fe de las comunidades afroamericanas en los EE. UU. Para la teología negra de la liberación: "El lenguaje de la teología lanza un desafío a las estructuras de la sociedad porque es inseparable de la comunidad sufriente. La teología nunca podrá ser neutra ni dejar de tomar partido cuando está en el tapete la condición de los oprimidos" (Cone, 1973, p. 18).
Así como hacemos con este ejercicio de localización desde las experiencias de fe de las comunidades afroamericanas, cuando hablamos de necroecoteología nos referimos a un concepto localizado, particularizado; su lugar de fermentación ideológica es la exterioridad periférica, dependiente, atrasada, subdesarrollada. La terminología la asumimos ontológicamente desde su relevancia histórica. El ímpetu destructor necroecoteológico, representado en las fuerzas de la muerte contenidas y extendidas en corrientes fundamentalistas de perfil político y religioso, ya sean cristianas o no, lo entendemos como arquetipo de dominio, control y exterminio, capaz de cruzar todas las expresiones socioculturales oprimidas.

El exterminio de los indios, la persecución de los judíos, la opresión de los mexicanos estadounidenses y cuanta inhumanidad se ha cometido en nombre de Dios y de la Patria, todas estas brutalidades podemos analizarlas en términos de la incapacidad de los Estados Unidos para reconocer la humanidad de los negros (Cone, 1973, p. 22).

Todo lo contrario, a la visión amorosa, compasiva y solidaria de la teología negra de la liberación, la teología de la liberación y demás expresiones culturales, filosóficas, teológicas y políticas, la necroecoteología es el rostro distópico, implosivo, del quehacer profético; negación de toda utopía 
esperanzadora. Según Hinkelammert (1978), antiutopía "porque reacciona a la utopía ..." (p. 3), la cual es la expresión de la negación de la esperanza alentada por la fuerza de la vida. Una religiosidad liberadora antes que necrótica, tanática, es erótica, sensual, ecoteológica, abarcadora y creadora. Desde el sentir de Bloch: "El único substrato hereditario significante de la religión: ser esperanza en totalidad, y una esperanza explosiva" (Bloch, 2007, p. 303).

La necroecoteología como racionalidad y subjetividad instrumental (abordaremos el tema más adelante) niega y destruye todo signo de vida en estado de vulnerabilidad. Las fuerzas tanáticas se presentan como defensoras absolutas de la esperanza, de la paz y la justicia, pero en la práctica sus compromisos son con la aniquilación individual y colectiva de estas mismas y la perpetuación de coloniales estados de realización. Como lo señalamos líneas arriba, una muestra de ello se expresa desde 1945 en adelante cuando la industria del control geopolítico global absolutizó y universalizó en una estructura de principios y valores de base jurídica las directrices legales del proyecto hegemónico de control y dominio sacrificial de cuerpos, territorios y espacios. Industria internacional que hizo de la religión, la teología, la ecología y la sanidad, instrumentos perfectos de injerencia y control geopolítico.
La inversión de valores del capitalismo global, y su estrategia de globalización, entiende todo tipo de apuesta por la vida como "distorsión de mercado", tal es el caso de los derechos humanos y "después de la eliminación de las distorsiones de mercado sigue la anulación de los derechos humanos ... en tanto derechos humanos de seres corporales". (Hinkelammert, 2003, p. 14; Cf. Hinkelammert, 1998b, p. 37).

Estas son las fuerzas proféticas de derechos universales hegemónicos. Corrientes de poder necroecoteológicos, verdugos de soberanías, particularidades y toda expresión de distorsión de mercado (derechos humanos, civiles, culturales, económicos, ambientales, de los pueblos, etc.) en nombre del proceso de globalización colonial y del divinizado mercado como única realidad universalizable y absoluta. La mano invisible o mano providencial de Adam Smith, y el fantasma de los chicagos boys escriben y mueven los tentáculos de la necroecoteología. Si existiera algún dicho despótico que se podría atribuir a estas fuerzas proféticas de la muerte sería uno de Calígula, emperador de Roma: "Quisiera que el pueblo tuviera un solo cuello, para cortarlo" (Hinkelammert, 2003, p. 61).

Baldó Lacomba (1993), citando a Marx (, 1867), resalta las relaciones y contradicciones sociales como parte inalienable del desarrollo capitalista 
el cual, desde una perspectiva necroecoteologica, se puede afirmar como la fuente de todo tipo de degeneración y desequilibrio generalizado de los ecosistemas. Las fuerzas económicas y políticas, subyacentes en el atentado contra forma de vida. Marx, en el primer volumen de El capital (1867), lo sintetiza desde una lectura donde resume la relación intrínseca entre sociedad capitalista-industrial e instrumentalización, por ende, desacralización, de la Tierra con fines acumulativos:

... la depredación de los bienes de la Iglesia-dice-, la enajenación fraudulenta de las tierras del dominio público, el saqueo de los terrenos comunales, la metamorfosis de la propiedad feudal en moderna propiedad privada: he ahí otros tantos métodos de acumulación originaria. Con estos métodos se abrió paso la agricultura capitalista, se incorporó el capital a la tierra y se crearon los contingentes proletarios libres y privados de medios de vida que necesitaba la industria de las ciudades (Marx, 1867, p. 624).

La cosmología despótica de las fuerzas necroecoteológicas se construyen sobre las bases de fetiches; dioses de barro, ilusiones en el desierto, efímeros espejismos del anhelado bienestar de un paraíso perdido sembrado de aparentes inofensivas mercancías. "A primera vista, una mercancía parece ser una cosa trivial, de comprensión inmediata. Su análisis demuestra que es un objeto endemoniado, rico en sutilezas y reticencias teológicas" (Marx y Engels, 2002, p. 22). Contra toda justificación que hasta el día de hoy se puede dar a proyectos de expansión geopolítica, con fines imperiales, sostenemos, al igual que Dussel (1983b), que el fundamento religioso de la necroecoteología no es cristiano sino pagano: “... el fundamento religioso del sistema no es cristiano sino pagano: idolátrico, fetichista. Muestra la contradicción de la religión de la Cristiandad consigo misma" (p.201).

El mercado parece ser entonces un dios que propone como única moral aceptable el conjunto de las leyes que lo regulan. No hay otra moral a aceptar sino la del mercado, que transforma en competidores y enemigos a quienes participan en él (a menos que hagan alianzas y contratos). En esta lucha que caracteriza al mercado libre hay quienes ganan y pierden, quienes sacrifican al ídolo y quienes son sacrificados. El ídolo no se satisface sin esta violencia. (Santa Ana, 1991, p. 44).

La necroecoteología, movida por esta suerte de mistica providencialista capitalista (Santa Ana, 1991, p. 60), se revela como la invisibilizada fuerza espiritual del Leviatán de Thomas Hobbes (1651). Animus y anima que sobrevuelan las profundidades del infierno, el abismo doloroso de Dante Aliguieri (12651321), el cual recordó en su época a los huéspedes del lugar eterno del dolor y 
sufrimiento: "esos sin pelo, que de un lado vemos, fueron clérigos, papas, cardenales, que la avaricia llevó a sus extremos ... cuán fugaces son los bienes que alarga la fortuna ... Todo el oro que está bajo la luna, y el que esa grey de sombras retenía, la paz no le dará, siquiera una" (Alighieri, 1944, p. 27).

El proyecto necroecoteologico es puesto en marcha desde la extrema individualidad del "ego cogito privatizado". La metafísica del proyecto depredador no es la alteridad e intersubjetividad. La razón totalizadora no tiene espacio para el Otro; el espacio en la exterioridad (periferia), en relación con el centro absolutizado, es objetivado con fines de apropiación y secuestro. La modernidad cartesiana inyectó en el ego conquistador europeo, corporativo, financiero, extractivista, transnacional, el complejo fundamentalista del ego cogito omnipresente, omnisciente y omnipotente. Como subraya Dussel (1974), el ser humano moderno, al destruir al Otro, destruye, y no suplanta, a Dios quedándose él mismo como totalidad: “... el hombre se queda solo como un ego solipsista, solitario, aislado, y ahora en lugar de llamar al ser fysis [una totalidad física], es una totalidad egótica, un sujeto" (Dussel, 1974, p. 265). El homo faber, aniquilador del sentido sagrado y creador de la alteridad, entró en escena. En la exterioridad donde reside el "no-ser", los nadies (Eduardo Galeano), solo hay lugar para el "hombre supremo de la totalidad" (Dussel) y como el "no-ser" (ser humano-naturaleza) está fuera de la totalidad, llega el ser-todopoderoso (ego cogito), y asesina al no-ser (CaínAbel). "Ego cogito que se encuentra en el "centro" de un mundo imperial como dominación racional de las "colonias" (las periferias). (Dussel, 1974, p. 131).

Las consecuencias del protagonismo del ego cogito, de la "autonomía del homo faber". y su sentido de libertad para destruir todo con tal de satisfacer sus comodidades, coloca todo signo de vida al borde del abismo. El aumento de gases de efecto invernadero como el óxido nitroso (N2O), dióxido de carbono (Co2) y metano (Ch4) han sido los signos del "progreso" y "desarrollo desenfrenado" desde las primeras humaredas a mitad del siglo XVIII, en Gran Bretaña, con los inicios de la primera Revolución Industrial. Las expectativas a futuro no son alentadoras, según aproximaciones de Kerber, realizadas hace diez años, se prevé el aumento de temperatura global $0,2^{\circ} \mathrm{C}$ por década en las próximas dos décadas; entre 1980 y 2090 el calentamiento del aire fluctuara entre $1,9{ }^{\circ} \mathrm{C}$ y $4,0{ }^{\circ} \mathrm{C}$ y "se espera un aumento de 18 a $59 \mathrm{~cm}$. del nivel medio global del mar, según escenario para finales del siglo XXI, 2090-2099 (Kerber, 2011, p. 188).

Por lo dicho, hablar de necroecoteología es hablar de eco-injusticia. 
Es hacer de la mitología del mundo perfecto, del mito del desarrollo y del mito de los recursos inagotables, argumentos fraudulentos para un mundo enajenadamente conducido a su autodestrucción (Gudynas, 2003). Ahora, por fuerza de contrarios, hablar de eco-injusticia necesariamente nos 1leva a la eco-justicia, de la mano con la ecosacralidad, como aquel reverso histórico que nos habló Gustavo Gutiérrez. Eco-justicia, según Gudynas , lo entendemos como el "cambio sustancial ... de pensar y sentir, en el cual el ambiente deja de ser una colección de objetos [recuperando] cualidades de sujetos ... la Naturaleza recupera valores propios que no dependen de la utilidad para los humanos" (Gudynas, 2017, p.20). Finalmente, Kerber coloca sobre la mesa la visibilidad orgánica de la eco-justicia: “... las víctimas del cambio climático empiezan a ser reconocidas ... 'refugiados climáticos' o "desplazados ambientales"”. (Kerber, 2011, p. 191).

\section{Claves necroecoteológicas en tiempo de pandemia}

Fundamentalismo político y religioso, genocidio, etnocidio, ecocidio, pandemia transversal, medidas coercitivas unilaterales, forman algunas claves hibridas de lectura e interpretación de escenarios de alta complejidad como los que el mundo atraviesa. Frente a la encubierta instrumentalización, in crescendo, de sentimientos religiosos, de perfil cristoneofascistas (Tamayo, 2021) desde perspectivas devastadoras de todo signo de vida, es necesario continuar abriendo diálogos donde la opinión ecoteológica se trascienda a sí misma desde percepciones no unilaterales de la sacralidad de la vida. Con esta finalidad, ensayamos tres propuestas de claves de discusión: 1. Medios y fines de comunicación; 2. Tecnocracia económica y neutralidad política; 3 . Métodos de control (genocidio, etnocidio, ecocidio y epistemicidio), y 3. Subjetividad instrumental.

\subsection{Primera clave. Medios y fi- nes de comunicación.}

La historia de los acontecimientos mediáticamente rentables, construida desde plataformas del género político-mercantil global y regional, es hilvanada de forma transdisciplinaria en donde los fines justifican los medios. La conciencia de la humanidad, y no solo por intereses de pérdida o ganancia corporativa, se encuentra en estado de emergencia, debido a la avalancha adoctrinadora, adormecedora y enajenante de la mass media; fábricas publicitarias de mentiras y distorsión de realidades. Matrices de opinión alquímicas, especializadas en absolutizar, cual infalibilidad canónica, verdades en mentiras, ignorancias en sabidurías, crímenes en errores, saqueos en custodia, extractivismo en desarrollo y 
progreso, etc. Y, todo ello, con la más impune normatividad y jurisprudencia amparada por el concierto cómplice del derecho internacional, promovido por organismos internacionales, como la OEA.

\subsection{Segunda Tecnocracia económica y neutralidad política.}

Ya Max Weber puntualizaba, como signo del "racionalismo económico", el sometimiento de todo el proceso de producción a "consideraciones científicas" en el marco del "ideal de vida de la moderna sociedad burguesa" (Weber, 2004). La responsabilidad política que Weber atribuye a corrientes religiosas no católicas sobre el desarrollo del capitalismo es muestra suficiente para continuar con discusiones en torno a la vigencia de la instrumentación de la religiosidad con fines mercantilistas, como el surgimiento del cristoneofascismo (Tamayo, 2021) lo puede demostrar. Desde esta perspectiva, no quepa lugar para neutralidades políticas desde visiones teológicas sobre problemas concernientes al mundo y su inmanencia histórica.

Argumentar neutralidad política de teologías (fe-espiritualidad), ecologías y sanidad pública (racionalidad-cientificidad) es el mantra mediático de las políticas liberales. Por ejemplo, no se puede hablar de neutralidad política sanitaria (pandemia), si en los dramáticos meses del estado de pandemia transcurrida, los EE. UU. han dictaminado más de cincuenta medidas coercitivas unilaterales en contra de la República de Cuba. Medidas unilaterales que han limitado, inhumanamente, el acceso a fármacos, instrumentales e insumos médicos, víveres de primera necesidad y todo tipo de acceso a procedimientos quirúrgicos de más de 11 millones 300 mil habitantes; esto, sin mencionar las medidas coercitivas unilaterales impuestas a países como la República Bolivariana de Venezuela, Nicaragua y otros.

La in crescendo industria hegemónica, en medio de la sutil proliferación de simbologías y mitos religiosos, de perfil económicamente totalitario $\mathrm{y}$ fundamentalista, instrumentaliza tecnócratamente el discurso político y religioso cotidiano (p.e. neopentecostalismo, ultraderecha católica, etc.) lo cual forma parte del proyecto neocolonizador y de su permanente búsqueda de impunidad jurídica y legislativa, al amparo del derecho internacional y de grupos de facto. Pero lo más dramático, de esta matriz del control de cuerpos, territorios y espacios, es la impunidad que se busca en la mente colectiva de los pueblos como parte de un santificado proyecto de inexistente apoliticidad religiosa bañada de matices metafísicos de espiritualidad contemplativa, acrítica y prósperamente esperanzadora; 
todo esto con matices simbólicos metafísicos (religiosidad instrumental) volcados a la consolidación de una ritualista, cultica, apolítica y acrítica cotidianidad enajenante y opresiva.

Gestos de apoliticidad y acriticidad se visibilizan como distingos de conductas democráticas y económicas de posiciones liberales y neoliberales. Regímenes teocráticos $\mathrm{y}$ tecnocráticos suelen sostenerse sobre principios provenientes de esferas teocráticas del poder constituido de tradición teológica colonial. No es raro encontrar consolidados regímenes liberales abiertamente confesionales (Concordato Estado-Santa Sede), de histórica tradición protestante o politizadas expresiones del neopentecostalismo cada vez más en crecimiento exponencial; aunque a todas voces se declare a la separación de poderes. Recordemos que la estructura de principios de la industria colonizadora del siglo XV es fundamentalmente teológico-filosófica y, en el siglo XVIII, las corrientes emancipatorias de América encontraron la esencia de su razón de ser en su autocomprensión de perfil metafísico y teológico, rasgo ontológico trascendido hasta nuestros días.

Descartes, Adam Smith, Milton Friedman siguen vigentes. Refritos ideológicos resucitados tal cual centenario marketing publicitario de la Coca Cola. Como es de conocimiento generalizado, el gurú de los chicos de
Chicago fue el que sostuvo que la historia de los Estados Unidos es la historia de un milagro económico y de un milagro político que fue posible por la puesta en práctica de ideas como la expresada en la Constitución de los EE. UU. de 1776. Constitución burguesa en la cual se proclamó el nacimiento de una nueva nación, un nuevo paradigma, sobre bases teológicas de una libertad del homo faber de matriz económica: "Mantenemos estas verdades por ser evidente que todos los hombres son creados iguales, que están dotados por el Creador de ciertos derechos inalienables, entre ellos la vida, la Libertad y la búsqueda de la Felicidad". (Friedman, 1962, p. 6). La consonancia filosófica sobre el sentido de la felicidad entre Friedman y Descartes se hilvana a la perfección. Derechos humanos (corporales), invertidos a derechos jurídicos, aseguran felicidad (consumo) y libertad (compraventa) para las almas elevadas (desarrolladas) sobre las almas vulgares (subdesarrolladas):

En palabras de Descartes:

... la diferencia que existe entre las almas más elevadas y las bajas y vulgares consiste principalmente en que las almas vulgares dejan arrebatar por sus pasiones y no son dichosas o desgraciadas más que en tanto en cuanto les acontecen sucesos venturosos o desdichados; mientras que las otras [almas elevadas] posee tal fuerza de raciocinio 
que, aunque también tengan pasiones, e incluso con frecuencia más violentas que el vulgo, su razón siempre, empero, la que manda, poniendo a su servicio esas mismas aflicciones y obligándolas a contribuir a la perfecta felicidad de que gozan ya en esta vida (Flórez, 2011, p.575).

Fue desde esta concepción necroecoteológica del poder que se produjeron, en el marco de derechos positivados, esclavitudes, desplazamientos, cristianización y exterminio de pueblos como los Chickasaw, Choctaw, Creek, Seminola y Cheroqui, así como de poblaciones de esclavos provenientes del África. La historia sin fin sigue hasta nuestros días con el exterminio de miles de personas alrededor del mundo. La depredación de miles de hectáreas de bosques y tierras al servicio de políticas económicas rentistas y primario extractivistas se extiende con la mayor velocidad y subrepticias formas jamás imaginadas.

\subsection{Tercera clave. Métodos de control (genocidio, etnocidio, ecocidio y epistemicidio).}

Violaciones contra la humanidad (poblaciones colonizadas) y depredación ambiental (zonas colonizadas) no solo son crímenes sino métodos arbitrarios coloniales de expansión geopolítica y control interno de naciones no alineadas. La jurisprudencia penal internacional suele sancionar el crimen, cuando se lo permiten, pero no el método que lo promueve. Tal es el caso de EE. UU. y el veto a las investigaciones sobre crímenes de guerra dirigidas a militares norteamericanos en Afganistán o las intervenciones arbitrarias de la OTAN, legitimadas por la Carta de las Naciones Unidas.

La destrucción de cuerpos y territorios son actos simultáneos; no existe uno sin el otro. El extractivismo primario minero se basa en la instrumentalización inhumana, y ecocida, de los miles de súbditos del desarrollo económico. Entidades cosificadas, embriagadas con ficticios espejismos de buen vivir (aplicado sobre la construcción del sistema del mal vivir) sucumben ante el todo poderoso mercado, aunque por sus venas corran plomo y mercurio, y sus pulmones combustionen toxicidad cancerígena y en medio de este tétrico y desesperanzador escenario la industria de la mass media, y operadores políticos, insisten en disociar el análisis teológico del político; la idea del presente artículo es demostrar la cohabitación inseparable de ambas posturas.

El modus operandi institucionalizado del terror es expresión genética de la naturaleza de los imperios; y no se registran imperios que hayan sobrevivido desvinculando la racionalidad y subjetividad política de la 
teológica y religiosa. Desde las intestinales cruzadas medievales, del sanguinario feudalismo europeo y semifeudalismo americano, a la esclavitud colonialista euro-norteamericana del siglo XXI, la instrumentalización del sacrificio humano y ambiental se convirtió en el tributo perfecto a fetiches. Ofrendas sostenidas por medio de espiritualidades opresivas, religiosidades enajenantes y epidemias teologizadas, entendidas como castigo divino aún en frágiles periodos de secularización como el de la actualidad; tiempos en donde supuestamente la racionalidad, como expresión de la "edad adulta" de la humanidad, desplazó todo vestigio de subjetividad religiosa.

El escepticismo secular postmoderno y la ausencia del elemento estético y religioso en la epistemología crítica, de índole eco-antropológica, política, social o económica, limita a la humanidad la posibilidad de desentrañar sus más arraigadas incógnitas, no resueltas, en cuanto a la violencia y su relación con lo sagrado como profundizaron historiadores, antropólogos, y etnógrafos, como René Girard (1989, 1995). Como hemos venido sosteniendo, la tendencia a erradicar del imaginario colectivo el elemento religioso, estético e histórico, de la arquitectura epistemológica y praxiológica del ser humano, lo único que ha logrado es perpetuar el enredo de la autodestrucción en un ilimitado concierto oscurantista de una espiral de violencia montada a imagen y semejanza del dios mercado y sus nefastos instrumentos de control.

El humanismo escéptico pasa por alto la crítica suprema de lo religioso cuando en realidad es su heredero, y, como todo heredero, demasiado interesado en la perpetuación del capital que hereda como para no ser secretamente respetuoso con él. En condiciones radicalmente alteradas por la revelación bíblica, el humanismo escéptico impide la revelación del papel desempeñado por el mecanismo victimario en la génesis y la organización de los mitos [estético]. Se sitúa en la prolongación directa de lo religioso victimario cuyo secreto protege (Girad, 1989, p. 53).

Teología, ecología y política sanitaria, vale decir, fe y razón, espiritualidad y cientificidad, se presentan como llaves vigentes e indesligables de la necesaria deconstrucción poscolonial a partir, por un lado, del reconocimiento de su instrumentalización con fines políticos y económicos $\mathrm{y}$, por otro, de la búsqueda incesante de resignificación de expresiones de organizada resistencia y esperanza activa transversal en todos los niveles del tejido social. $\mathrm{Fe}$, naturaleza y corporeidad han sido elementos racional y subjetivamente instrumentalizados a punto de convertirlos en pilares ideológicos del control y dominio de cuerpos, territorios y espacios, y este hecho, por más que 
suene repetitivo hacerlo, es necesario contextualizarlo y visibilizarlo del escenario del análisis y organización de la sociedad civil como lo sigue haciendo Santa Ana,

El mercado parece ser entonces un dios que propone como única moral aceptable el conjunto de las leyes que lo regulan. No hay otra moral a aceptar sino la del mercado, que transforma en competidores y enemigos a quienes participan de él (al menos que hagan alianzas y contratos). En esta lucha que caracteriza al mercado libre hay quienes ganan y quienes pierden, quienes sacrifican al ídolo y quienes son sacrificados. El ídolo no se satisface sin esta violencia (Santa Ana, 1991, p. 44).

En esta necesidad de subrayar variables de interpretación religiosa, como punto de partida en el marco metodológico de la necroecoteología, vemos necesario, a manera de introducción, agregar el terror como variable de interpretación religiosa de las reflexiones posteriores. Las fuerzas coloniales, sin el terror infundido, por medio de la cruz y la pólvora, hoy por medio de medidas coercitivas unilaterales, hubiesen visto el fracaso a la vuelta de la esquina. Fue por medio de la pólvora, de animales de carga, de unidades de transporte, del fundamentalismo religioso y de plagas biológicas con las cuales se hizo del terror el eje central del control y establecimiento de huestes enigmáticas y todopoderosas provenientes de otros mundos.

El quiebre relacional que significó el proyecto colonizador fue facturado por un desorden social, ecológico y biológico insurgido ante la ruptura del sagrado vínculo de la corresponsabilidad de todo ser animado o inanimado. La ritualidad de la danza de la muerte promocionada a los cuatro vientos como resultado del Covid-19 (SARS-CoV-2) o la variante Delta Plus (K417N) reflejan, en palabras de Boff (2021d), "una situación de caos completo, caos destructivo de millones de vidas humanas ... El virus deriva de múltiples variantes; es su triunfo sobre nuestras células". Según lo descrito por López de Gomara, "Los indios morían como moscas; sus organismos no oponían defensas ante las enfermedades nuevas. Y los que sobrevivían quedaban debilitados e inútiles ... Llamaron los indios a este mal huizauatl, que suena la gran lepra" (López de Gomara, 2009, p. 198).

Las bacterias y los virus fueron los aliados eficaces. Los europeos traían consigo, como plagas bíblicas, la viruela y tétano, varias enfermedades pulmonares, intestinales y venéreas, el tracoma, el tifus, la lepra, la fiebre amarilla, las caries que pudrían las bocas. La viruela fue la primera en aparecer. Los indios morían como moscas; sus organismos no oponían defensas ante 
las enfermedades nuevas. Y los que sobrevivían quedaban debilitados e inútiles (Galeano, 2004, p. 35).

Ninguna diferencia con la industria bélica bacteriológica usada desde 1945 a la fecha. Teologías de la prosperidad, modernidad, desarrollo $\mathrm{y}$ ritualidades de la religiosidad del sistema del libre mercado (chivos expiatorios y sacrificios) forman parte del relato mítico cosmogónico imperante. Cosmovisiones sacrificiales en donde cuerpos, territorios y espacios sufren la desquiciada cosificación antropocena y necrocena, entendida como "la agresión sistemática que los seres humanos ejercemos contra la naturaleza y la Madre Tierra" (Boff, 2021c).

Desde la esfera económica, el mismo fenómeno destructivo necrocolonizador, medidas coercitivas unilaterales (bloqueos económicos, financieros $\mathrm{y}$ comerciales) como armas de destrucción masiva de última generación. Estos últimos métodos coercitivos son, incluso, avalados por la Carta de las Naciones Unidas en su capítulo VII del Consejo de Seguridad: Acción en caso de amenazas a la paz, quebrantamientos de la paz o actos de agresión.

\subsection{Cuarta clave. Subjetividad instrumental.}

Antes de incidir en el análisis crítico del desastre ecológico, desde variables de afectación económica y sociológica y ahondar en ecuaciones de contaminación ambiental o porcentuales de plusvalía obtenida como resultado de economías primario extractivista (temas de especialistas), reflexionamos en el modelo paradigmático colonial y neocolonial religioso. Desde esta premisa, nos aproximamos a la arquitectura discursiva sobre la cual se sostiene el termino al cual estamos denominando necroecoteología.

Sin obviar abordar la necroecoteología desde el prisma de la racionalidad instrumental, lo hacemos desde lo que proponemos como subjetividad instrumental; puerta metódica a áreas epistemológicas y praxeológicas instrumentalizadas como la religiosidad, la teología y la estética. La subjetividad instrumental es la variable convertida en elemento destructor del ser humano, entendido como subjetividad trascendental, por Leonardo Boff, interpuesta "sobre todo lo que afecta al mundo en términos de dominación, de lucro y de explotación" (Boff, 1978, p. 48). Por otro lado, paragonando a Franz Hinkelammert (1984), cuando aborda la rebelión de la subjetividad contra de la racionalidad instrumental, la rebelión que asumimos, en medio del conflicto originado por la necroecoteología, sería desde un ejercicio racional y subjetivo creador, contra una subjetividad instrumental, racional y objetiva. Desde una visión invertida de lo sostenido 
por Horkheimer (1969), sobre la razón subjetiva, particularidad enfatizada por Galafassi (2002), la subjetividad instrumental, fundamento ontológico de la necroecoteología, visualiza, planifica, construye y dogmatiza imaginarios estéticos y simbólicos orientados hacia finalidades preestablecidas por un orden religioso-teológico-filosófico-eclesiástico estrecha, e inseparablemente, ligado a un orden jurídico y legislativo (derecho canónico + derecho romano $=$ orden establecido) .

Desde la perspectiva de la Escuela de Frankfurt, Horkheimer habla, por un lado, de la razón objetiva, la cual "aspira a sustituir la religión por el pensar filosófico metódico y por la comprensión a convertirse así en la fuente de tradición" y, por otro lado, de la razón subjetiva, la cual "se inclina a desistir de la lucha con la religión [estableciendo rubros diferentes como], la ciencia, la filosofía y la mitología institucionalizada, reconociendo ambas". (Horkheimer, 1969, p. 24). Todo lo contrario, a lo sostenido por Horkheimer, desde la necroecoteología, la subjetividad instrumental, antes que eliminar la religión, propio del iluminismo y la racionalidad instrumental, la racionaliza como instrumento pragmático $\mathrm{y}$ estético de control y subordinación de sistemas de producción material y organización social, legitimados y legalizados como estructura fundamental de un nuevo paradigma colonial. Veamos, como ejemplo, cada vez más en investigación, factores religiosos como el neopentecontalismo, y la teología de la prosperidad en evolución permanente, cada vez más presentes en el escenario político local, regional e internacional desde los perfiles más macabros de la política como son el fundamentalismo fascista-religioso al cual Juan José Tamayo ha bautizado, desde la experiencia del siglo XX-XXI, como cristoneofascismo.

Fascismo y religión son dos fenómenos que históricamente han mantenido una relación de complicidad, que ha desembocado con frecuencia en sistemas dictatoriales, nacionalismos populistas de derecha excluyentes y regímenes confesionales que niegan la libertad de conciencia, persiguen el librepensamiento y legitiman el patriarcado (Tamayo, 2021).

En suma, la racionalidad objetiva instrumental del colonizador se valió de la subjetividad instrumental, o de la instrumentalización de la subjetividad, ensayada y dirigida a objetos colonizados (humanos-naturaleza), subjetivación per se incluida en el iusnaturalismo que logra construir el hibrido entre individuo irracional (colonizado) e individuo racional (colonizador). Nos referimos al androide homo religious-homo ceconomicus, el cual trataremos más adelante. Por principio, el iluminismo tenía como 
objetivo empoderar al ser humano liberándolo del miedo a lo sobrenatural, convirtiéndolo así en amo y señor de seres humanos y naturaleza instrumentalizada (Horkheimer y Adorno 1969), en las colonias pasó todo lo contrario. El iluminismo colonizador introdujo el miedo a lo sobrenatural en tierras arrasadas, convirtió la esclavitud y sumisión a la corona e iglesia en estigmas inseparables de una versión imperial del modernismo.

La subjetividad instrumental, y la estructura sincrética religiosa configurada como experimento colonial, base religiosa, teológica y filosófica de la necroecoteología, resignifica el concepto de superstición y magia, desplazándola de la religiosidad y espiritualidad originaria, hacia procesos religiosos y teológicos impuestos por medio de la Cristiandad; hoy su versión actualizada, contextualizada y tecnologizada la encontramos en el cristonesofascismo, antes mencionado. Vale decir, la subjetividad instrumental colonial se encargó de reemplazar la estética originaria (mitos y símbolos) por una estética basada en miedos teológicos como el pecado, infierno, cielo, resurrección, perdón, gracia, plagas (enfermedades), etc., imaginarios sociales creados y recreados con fines de control en Europa ante de la llegada a tierras invadidas: "La realidad latinoamericana es una realidad-espejo, pero no una realidad-fuente" (Boff, 1978, p. 46).
Entonces, el colonizador, fiel a la racionalidad objetiva y subjetiva, se presentó, exactamente, como amo y señor del ser colonizado y de la naturaleza, domesticando y controlando a ambos; reinterpretando el mandato del Génesis y añadiendo el elemento antropológico (colonizador) a los objetos de dominio. Mientras que la subjetividad instrumental antes de valerse del intelecto como instrumento de liberación de la superstición y magia, las cuales no se permitía el Iluminismo, se valió de la nueva estructura intelectual colonial secular-religiosa, y del conocimiento necroecoteologizado (epistemicidio).

\section{Marx y necroecoteología}

No es la idea del presente profundizar el concepto de fetiche en Marx asociándolo con el sentido idolátrico de la espiritualidad necroecoteológica. Más aún si Dussel colocó pródigamente la extensa información del fetichismo en las cuatro redacciones de $E l$ Capital (1857-1882) divididas en: El fetichismo en la primera redacción de El Capital (desde 1857); el fetichismo en la segunda redacción del El Capital (1861-1863), el fetichismo en la tercera redacción del El Capital (18631865) y el fetichismo en la época de la última redacción de El Capital (18661882). En esta oportunidad, Marx viene a nuestro encuentro en la medida que nos ofrece la clave de conexión 
histórica de la necroecoteología, o como diría Dussel: el mismo mecanismo ideológico de analogía histórica, con religión, capitalismo y economía: el fetichismo.

De ahí que para hallar una analogía [una metáfora] pertinente debamos buscar amparo en las nebulosas comarcas del mundo religioso. En este, los productos de la mente humana parecen figuras autónomas, dotadas de vida propia, en relación unas con otras y con los hombres. Otro tanto ocurre en el mundo de las mercancías con los productos de la mano humana. A esto llamo el fetichismo que se adhiere a los productos del trabajo ... ese carácter fetichista del mundo las mercancías (Warenwelt) se origina ... en la peculiar índole social (gesellschaftlichen) del trabajo que produce mercancía (Dussel, 1993, p. 86)

Es desde la abstracción teológica de Marx sobre El Capital, ya sea desde la alegoría del pecado original o del sentido fetichista de la mercancía, donde la necroecoteología adquiere teológicamente corporeidad histórica. Marx evidencia, en el capítulo 24 del Capital, la llamada acumulación originaria. El secreto de la acumulación, como trasfondo mitológico relacionado con el principal sostenedor del capitalismo, el monoteísmo judeocristiano:

Cierto que la leyenda del pecado original teológico nos cuenta cómo el hombre se vio condenado a ganarse el pan con el sudor de su frente, mientras que la historia del pecado original económico nos revela cómo hay gente que para ganarse el pan no necesita sudar, ni muchos menos. No importa (Marx y Engels, 2002, p. 891).

La mercantilización de las relaciones sociales y de producción se convierte en la clave de interpretación del círculo relacional idolátrico de la necroecoteología. En palabras de Marx: "A esto llamo el fetichismo que se adhiere a los productos del trabajo no bien se los produce como mercancías, y que es inseparable de la producción mercantil". (Marx y Engels, 2002, p. 44). La tendencia a la cual nos vemos impulsados, por las alusiones de Marx a la religiosidad, y su influencia enajenante, es considerar, de plano, la inversión teológica de la tesis necroecoteológica que proponemos. Por un lado, se sostiene explotar la Tierra en beneficio del ser humano por mandato divino, y, por otro lado, los únicos beneficiados de dicha explotación son los propietarios de los medios de producción (minerales, agua, arboles, etc.); lo cual no es mandato divino sino lógica depredadora del sistema capitalista.

Debemos situar la crítica de Marx a la religión en su nivel no-teológico, como praxis histórica de la liberación ... no se trata de buscar una nueva interpretación teológica de la 
realidad, sino de lo que se trata es de transformar la realidad y en esa práctica transformadora de la realidad buscar una nueva inteligencia de la fe (Richard y Torres, 1975, p. 46).

Las bases doctrinales de la necroecoteología son ilusorias y opresoras antes que confesionales, históricas y emancipadoras. Desde ese punto de vista, todo principio ecológico y teológico, así como psicológico, sociológico, filosófico, político, ideológico, tecnológico, científico, artístico, estético, etc., que instrumentaliza al ser humano y la creación con fines mercantiles, es opio y verdugo del pueblo. La necroecoteología no cuenta con el ser humano, la naturaleza y la historia como lugares teológicos de revelación. Todo lo contrario, encuentra sus lugares de materialización en la mercancía, el dinero y el mercado; no transforma creativamente la realidad sino la destruye opresivamente. Es así como el fetichismo, como carácter místico de la mercancía (Marx), desde la visión tanática de la necroecoteología, construye fantasmagóricos sistemas de relaciones económicas, con total ausencia de intersubjetividades, otorgándole vida artificial a las cosas, y a partir de allí estructura jerarquías idolátricas en los diferentes paraísos mercantiles.

Como sabemos, el fetiche contiene diferentes acepciones: del latín facticius (artificial) y del portugués feitiço (magia, manía, hechizo, sortilegio), it. feticcio. El diccionario de la Real Academia lo define como: Ídolo $\mathrm{u}$ objeto de culto al que se atribuyen poderes sobrenaturales, especialmente entre los pueblos primitivos. Para Gallardo, ampliando y desarrollando las dimensiones del término, señala: "el fetiche es un producto humano o una relación histórica desligada de sus productores y de sus condiciones reales de producción, independizada de esta producción, y que retoma sobre los seres humanos para dominarlos y esclavizarles, para someterlos a sus caprichos, orden o lógica" (Gallardo, 1990, p. 16). Y, es así como desde este idolátrico modus operandi surge la necroecoteología. Variable de análisis e interpretación, entendida como estructura ideológica de dominio, resultado de la inversión de valores teológicos evangélicos y de la institucionalización de la cristiandad como sistema de creencias en la estructura de poder colonial y neocolonial. A este punto Hinkelammert coloca el punto de inflexión, de perfil asociativo, entre cristiandad y cristianismo, relacionado al carácter hegemónico y unilateral de una religiosidad que se impuso al islamismo y judaísmo con ansias de una ambigua emancipación que nunca supo exportarse a extramuros en el vertiginoso proyecto colonizador: 
El cristianismo imperial corresponde a la imperialización del cristianismo. Imperio y cristianismo se pueden encontrar solamente para una transformación mutua. El imperio asume el cristianismo en cuanto que éste puede aportar al poder imperial. El cristianismo, para poder cristianizar al imperio, tiene que transformarse en cristianismo imperial. Para que el imperio sea cristiano, el imperio debe ser la instancia a partir de la cual se lea e interprete al propio cristianismo (Hinkelammert 1998a, p. 208).

De allí nos preguntamos: ¿Cómo se explica que sobre las bases de las buenas nuevas del cristianismo se levantan terroríficas escenas apocalípticas de evangelización y todo tipo de prácticas necroecoteológicas en donde enfermedades, masacres, depredación y toda una variedad de actos destructivos se convirtieron, y convierten, en uno de sus principales instrumentos de sumisión? Suess sintetiza aquella diferencia que encontramos entre cristianismo y cristiandad; entre comunidad de fe y establischment, entre necroecoteología y ecoteología, entre ortodoxia y ortopraxis, entre doctrina y dogma:

La integridad del Evangelio no garantiza la integridad de la acción histórica de los evangelizadores. Si bien la destrucción de vidas y la colonización de pueblos no encontró argumentos en el evangelio, de hecho, encontró colaboradores entre evangelizadores. En nombre del
Evangelio, cristianos destruyeron sinagogas de judíos, santuarios de moros y templos paganos, quemaron "brujas y herejes (Suess, s. f., p. 8).

La historia de la cristiandad da evidencias de prácticas necroecoteológicas, en las cuales el aniquilamiento del otro-contrario es considerado testimonio fundamental en el marco de la doctrina de fe. Convertir al no cristiano y aniquilar al hereje fueron testimonios de fe. En el siglo IV, los inicios de la Cristiandad, anatemizar al otro y bienaventurar al cristianismo fue la norma. Ambrosio (339-397), obispo de Milán, en el año 388, defendió los incendios de la sinagoga de Killinitón (río Eufrates) y calificó la sinagoga de "un lugar de la incredulidad, la patria de la ausencia de Dios". San Bernardo de Clairvaux (1090-1153) y su tratado Las glorias de la nueva milicia templaria (1130), militarizó el quehacer misionero enviando a los soldados de Cristo "sin temor alguno de pecar por ponerse en peligro de muerte y por matar al enemigo. Para ellos morir o matar por Cristo no implica criminalidad alguna y reporta una gran gloria" (Suess, s. f., p. 8).

San Bernardo de Clairvaux (Claraval):

Consideraba que la Iglesia Católica podía llamar a las armas a las naciones cristianas para salvaguardar el orden establecido por Dios. Según 
él, si Dios juzgaba necesario que los ejércitos defendieran su reino, si el mismo Papa le ordenaba predicar la Cruzada, estaba claro para él que se trataba de una misión divina. Por tanto, transmitió a los cristianos que se trataba de una guerra santa, pues así la concebía él (Soberana Orden Templaría, 2020).

El fetiche de San Bernardo, ídolo que se alimentaba de la sangre del contrario (islam) y la preservación de los suyos, fundamentó su necroecoteología, aquel control voraz sobre cuerpos y territorios conquistados, sobre la división del mundo entre seres desconocidos- monstruosos, y seres conocidos-divinizados. El mismo San Bernardo se preguntó: “¿Qué vienen a hacer en nuestros claustros donde los religiosos deben dedicarse a las santas lecturas, esos monstruos grotescos, esas extraordinarias bellezas deformes y esas bellas deformidades?" (Cirlot, 1990, p. 175; Cf. Diez, 1955).

Las cruzadas medievales, como antesala del ecocidio y genocidio del siglo $\mathrm{XV}$ en adelante, consideraron la otredad islámica, judía $\mathrm{y}$, posteriormente inca, maya, azteca, guaraní, mapuche, etc., desde las esferas cultural, religiosa, económica, estética y geopolítica, como realidades de naturaleza monstruosa, contraria y, por lo tanto, destructible. "La alteridad de Oriente respecto a Occidente justifica también la otredad de sus criaturas. El lugar del monstruo llamaríamos 'lo extraño', en el mundo medieval es el monstruo. Diverso, desigual, situado en la zona desconocida que es Oriente" (Cirlot, 1990, pp. 180181; Cf. Boff, 1985, p.270).

En este marco de abstracción excluyente del otro vulnerable (ser humano-naturaleza), la relectura, reinterpretación y contextualización de las bases mitológicas judeocristianas se fundamenta sobre el sacrificio como culmen litúrgico del culto al fetiche. De igual forma, el ego conquistador, pensante, racionalizador, autónomo, libre y culto, bajó de las embarcaciones provenientes de Europa en el siglo XV, como ahora descienden de portaviones y aviones provenientes de costas norteamericanas en pleno siglo XXI, no arropados de un credo de fe sino de una ideología imperial. No existe mitología totalizadora que pueda servir de fundamento a proyectos genocidas y ecocidas sino se asientan en el sacrificio de ese otro débil, vulnerable, inofensivo.

Para Dussel, "los dos mitos, el Adán y el de Caín y Abel, indican exactamente lo mismo: el fratricidio como fetichismo. La muerte del Otro es la primera falta "... es totalización y la totalización es justamente el mal" (Dussel, 1977, p. 63). Por otro lado, Frei Betto nos aproxima a una concepción económica del fetichismo; aproximación que, sin dejar de ser teológica, se muestra secular, permitiéndonos 
realizar la relectura, que ya hemos venido sosteniendo desde la necroecoteología, como expresión sintética de proyectos geoexpansivos anti-vida.

El mercado, el nuevo fetiche religioso de la sociedad que vivimos. Antes, por la mañana, nuestros abuelos consultaban la Biblia. Nuestros padres el servicio de meteorología. Hoy se consultan los índices del Mercado. Ante una catástrofe o un acontecimiento inesperado dicen los comentaristas económicos: "Veamos cómo reacciona el Mercado". Y yo imagino un señor Mercado, encerrado en su castillo y gritando por el celular: "No me gustó el discurso del ministro. Estoy enojado". Y a esa misma hora los telediarios destacan: "El Mercado no reaccionó bien ante el discurso ministerial". El mercado es internacional, globalizado, se mueve según sus propias reglas, y no de acuerdo con las necesidades humanas. De hecho, predomina la globocolonización, la imposición al planeta del modelo anglosajón de sociedad. Centrado en el consumismo, en la especulación, en la transformación del mundo en un casino global (Betto, 2012).

De igual forma, para Hinkelammert: "El Dios del progreso infinito sustituye todos los demás dioses anteriores, quienes mantienen sus nombres, pero son cambiados por este Dios nuevo [mercado-fetiche], que es más celoso todavía de lo que habían sido los otros" (Hinkelammert, 2003, p. 107). Los pactos de las nuevas alianzas religiosas se dan entre abstractos nuevos sujetos sacerdotales como la tecnología, empresas, gobiernos, grupos de poder, lobbies, entidades financieras, carteles del narcotráfico, industria del armamento, industria farmacológica. El discurso paradisiaco tecnócrata-económico (intramundana) suplantó la utopía teológica (ultramundana) sin que en ello se pierda la naturaleza y el sentir religioso (religare), metafísico y trascendental de las aspiraciones últimas del homo øeconomicus. Y, para nuevos sujetos sacerdotales se requiere nuevos objetos eclesiales como las entidades financieras, hospitales, medios de comunicación, corporaciones empresariales, asociaciones políticas multilaterales (p.e Grupo de Lima, Alianza del Pacifico, Foro para el Progreso de América del Sur (Prosur), entre otras salas de parto del homo reconomicus.

\section{Necroecoteología y homo aeconomicus}

La modernidad (siglo XV) trajo consigo el androide homo religious-homo oeconomicus. Aún en el siglo XV, el poder imperial y el eclesiástico cohabitaban como una sola esencia. El proceso posterior de secularización europea (siglos XVII y XVIII) persistió en no desvincular poder religioso y político. Proceso de la denominada racionalidad civilizatoria en donde la razón, 
aun desplazando la fe-desde el plano filosófico-académico, no logró detener la fusión del poder secular-religioso en los pueblos colonizados. La persistencia de esta fusión fue necesaria en el marco del proyecto colonizador, valiéndose de ello como el principal instrumento de control de cuerpos y territorios invadidos.

¿Pero cómo explicar esta suerte de oxímoron secularización religiosa? Foucault construyó el análisis comparativo entre poder político y poder pastoral, visión desde la cual quedó claro el entramado confesional de lo que llamó el Estado-providencia (Foucault, 1989 , p. 53) y la tecnología del poder construida en base al paradigma del homo æeconomicus colonizado: devoto (religioso) y depredador (extractivista). Concepción antropológica, filosófica y sociológica moderna que abrió las puertas a una construcción teológica colonizadora paralela a la canónica donde el paraíso/mercado estaría compuesto de descendientes directos de Adam y Eva (cristianos) y salvajes paganos (indios), objetos de adoctrinamiento y pastoreo.

Los principios de gobernanza colonial se estructuraron sobre las bases, políticas y religiosas, de lógicas necroecoteológicas desarrolladas en doctrinas como el dominio antropológico del mundo y la lógica del pastoreo del redil de ovejas; la perfecta fusión del poder colonial dividido entre el mundo civil y el eclesiástico. En ambas posturas, el homo reconomicus es posicionado como el centro del universo, tanto en su versión colonizadora como colonizada, tanto desde su versión teológica como política.

El homo xeconomicus hecho a la imagen y semejanza de la trilogía del poder: Capital, mercado y mercancía/ dinero, construyó una matriz ecoteológica en donde la estructura política confesional europea, luego nor-europea, trasfirió el peso simbológico del templo (Santa Sede) al mercado (Corona/banca), pariendo el androide homo religious-homo ceconomicus. De Europa salieron el siglo XV, a tierras por colonizar, proyectos de cristianización y saqueo. El paraíso/mercado colonizado se convirtió en el lugar teológico, escenario de conversión no de bestias salvajes incivilizadas a la fe y gracia divina, sino de estas convertidas al nuevo orden mundial capitalista instaurado en las Indias.

Solo con América pudo el capital consolidarse y obtener predominancia mundial, deviniendo precisamente en el eje alrededor del cual todas las demás formas fueron articuladas para los fines del mercado mundial. Solo de ese modo, el capital se convirtió en el modo de producción dominante. Así, el capital existió mucho tiempo antes que América. Sin embargo, el 
capitalismo como sistema de relaciones de producción, esto es, el heterogéneo engranaje de todas las formas de control del trabajo y de sus productos bajo el dominio del capital, en que de allí en adelante consistió la economía mundial y su mercado, se constituyó en la historia sólo con la emergencia de América. (Quijano, 2000, p. 734).

Para Quijano, la constitución de América, la implantación de un "nuevo patrón de poder de vocación mundial" (p. 714), el paraíso/mercado terrenal del homo œeconomicus colonizado y colonizador, evangelizador necroecoteológico, se dio en el marco de un capitalismo colonial/moderno eurocentrado como un nuevo patrón de poder mundial. Según Quijano, el capitalismo y la modernidad llegaron al mismo tiempo. A su vez, Bolívar Echevarría describió los periodos de cristianización antes y después de la invasión europea en América.

En la Edad Media el proyecto consistió en convencer del significado y valor de la ecclesia como "cuerpo de Dios". En los inicios históricos de la modernidad (siglo XV y siglo XVI) la idea fue resignificar la asociación Iglesia-Corona, con nuevos conceptos de valores antropológicos, en donde "el mercado [se convirtió en] el sitio en donde el buen funcionamiento de la circulación mercantil de los bienes producidos [permitió] a los individuos sociales, sobre el común denominador de 'propietarios privados', reconocerse y aceptarse recíprocamente como personas reales" (Bolívar, 2011, p. 112).

La idea en nuestro tiempo no pasa por acabar con el homo religious-homo xeconomicus, ni por pactar con el poder eclesiástico en aras de la emancipación, como Bolívar se vio obligado a hacer. El proyecto liberador pasa por resignificar el proceso desde una praxis emancipadora que parta del sentido de la sacralidad de la vida, logre transitar caminos descolonizadores desde una Necroecoteología enajenante y alienante hacia, lo que estamos denominando, una ecosacralidad liberadora, plurirreligiosa y laica, como estadio superior de una práctica ecoteológica que en sí pueda acceder a imaginarios colectivos religiosos, fuente de miedos y terrores, anclados en la estructura histórica y simbólica arcaica de la humanidad.

\section{Necroecoteología y cultura del terror}

Las diferentes definiciones de terror coinciden en definirlo como el estado de conmoción y desajuste psico-emocional superior al miedo. Las raíces en latín tre son asociadas con verbos como tremo (temblar) y adjetivos como trepidus (agitado, tembloroso, inquieto). El Diccionario de la Real Academia lo define como miedo muy intenso. Por ejemplo, como parte del 
guion hegemónico, el uso del terror en la esfera política a nivel global por medio de medidas coercitivas unilaterales, aplicadas de forma impune contra gobiernos contra hegemónicos, cuenta con el aval cómplice de esferas de poder internacional y esa metodología del terror goza de impunidad tanto en el mundo de la diplomacia como el de la academia. Marx en El capital relaciona estas arbitrarias medidas de sujeción como el sistema colonial, la deuda pública, el moderno sistema impositivo y el sistema proteccionista colonial, no con el terror sino con la violencia como motor del proceso de "transformación del modo de producción feudal en modo de producción capitalista ... para abreviar el proceso de transiciones ... la violencia es la partera de toda sociedad vieja preñada de una nueva. Ella misma es una potencia económica" (Marx y Engels, 2002, p. 999).

Estas medidas coercitivas unilaterales, violentos instrumentos jurídicos, son estructurados cual mecanismos de castigo divino-humano aplicados por fuerzas omnipotentes con licencia para destruir y construir todo a imagen y semejanza del modelo liberal imperante. Denunciar la sistemática y sistémica violencia corporativa de las tierras, el control de territorios con arbitrarios monocultivos, así como denunciar el xenofóbico y colonial desplazamiento y explotación de las poblaciones rurales e indígenas, así como de multitudinarias caravanas provenientes de África a Europa o de Centroamérica a EE.UU., se ha convertido en la causa de uno de los más cruentos modelos del crimen impune de Estado (Foro de São Paulo, 2021).

Achille Mbembe subraya la absoluta ausencia de ley como resultado de la "negación racista de todo punto común entre el conquistador y el indígena ... [en donde] el terror colonial se [entremezcló] ... incesantemente con un imaginario colonialista de tierras salvajes y de muerte, y con ficciones que crean la ilusión de lo real" (Mbembe, 2006, pp. 40-41). Terror proveniente de dos fuentes de control: fe y razón. Instrumentos por medio de los cuales cuerpos y territorios fueron convertidos, en el mismo nivel de valoración, en objetos de sumisión social, cultural e instrumentos de esclavitud económica y laboral.

A la necropolítica de Mbembe, la necroecoteología agrega la variable fe y razón, variables despolitizadas y desligadas entre sí, ocasionando la regresión a un pasado plagado, por un lado, de subjetividades fundamentalistas y, por otro, de racionalidades mecanicistas. Paradójicamente, todo este escenario acontece en medio de una hiperinflación jurídica del derecho internacional, derechos humanos, derechos de los pueblos indígenas y derechos ambientales, entendidas como 
líneas rectoras transdisciplinarias de la defensa de la vida sin lugar a dualidades excluyentes. En esta suerte de "paraíso jurídico global", donde impera la anarquía del derecho positivado, profesado y usado como estandarte de la democracia y paz global, preguntamos: ¿Cómo es posible que en nombre del derecho internacional, de la paz mundial y de dios, se siga haciendo de mecanismos de terror, instrumentos impunes de control y devastación geoexpansiva?

\section{Necroecoteología, ecoteología y ecosacralidad}

Hasta ahora todo lo elaborado pareciera girar en torno a una comprensión monoteísta de la religiosidad de los pueblos y no estaría fuera de lo cierto verlo de esa forma. Ciertamente, no hemos desarrollado, como parte del marco teórico y conceptual de la necroecoteología aproximaciones diferentes al monoteísmo judeocristiano por más que las bases históricas de la necroecoteología las hemos construido, básicamente, a partir del periodo inicial de la llegada de Europa a tierras invadidas. El sentido del mesianismo tecnológico del cual nos habló Boff trasciende cualquier tipo de paradigma monoteísta, politeísta, panteísta o gnóstico que podamos imaginarnos. La trasversalidad de la institucionalización y culturización de la inhumana racionalidad instrumental y violencia híbrida que hemos visto, si bien es cierto encuentra su asidero en imaginarios y escenarios de poder basados en construcciones teológicas, filosóficas, religiosas y culturales de origen judeocristiano, esto no quiere decir que el sentido de la sacralidad de la pluralidad de cosmovisiones de la humanidad se encuentre fuera del fenómeno de naturaleza destructiva como hemos conceptuado a la necroecoteología.

El proceso actual de mundialización se hace en el cuadro capitalista, no por la vía religiosa, ética o ideológica, sino por vía del mercado total, cuyas necesidades son atendidas por la ciencia y por la técnica (las necesidades del mercado no son generalmente las necesidades de los seres humanos). (Boff, 2000, p. 129)

El dramático y terrorífico escenario mundial en donde la miseria prevalece por doquier, la agonía de la vida y el desagarro de la sinrazón de la muerte prematura, toca las fibras más profundas de seres que desfallecen cada segundo; desequilibradas ansias autodestructivas debido a las consecuencias del usufructo del poder de pequeños grupos en el planeta. La urgencia de lo vivido, y por vivir, requiere que seamos los primeros críticos de nuestras criticidades. Hablar de necroecoteología y ecoteología de una manera u otra circunscribe nuestras reflexiones, análisis y acciones en torno a creencias religiosas, por más abiertas e inclusivas 
que sean, al limitado mundo estético de los orígenes judeocristianos. La religiosidad y teología, en relación con el significado de naturaleza, no necesariamente son variables inclusivas del sentido de lo sagrado. Boff (2021a), recordando planteamientos de líderes y lideresas indígenas sobre el paradigma de "salvaguardar el mundo", subraya la necesidad de pensar la Tierra no como Gran Madre, Pachamama o Tonantzin sino [salvaguardar] de manera natural el mundo, porque lo [sentimos] como una extensión de [nuestro] propio cuerpo.

Desde la necesidad de trascender limitantes de racionalidades y subjetividades tanáticas, monoteístas, fetichistas e idolátricas, hacemos eco de la pregunta del fray Éloy Lecrerc, recordado por Boff (2021b), “¿cuál es el gran obstáculo que impide la fraternidad humana y con todas las criaturas, $\mathrm{y}$ que crea espacio para las masacres y la eliminación sumaria de personas consideradas inferiores o subhumanas, como ocurrió en los campos de exterminio? La voluntad de poder y el poder como dominación".

En suma, la urgencia de resignificar lo sagrado, como parámetro de valoración de la importancia de la vida per se, lo resume el jefe Seattle (17861866) ante la propuesta de compra de territorios de la población Suwamish por del presidente de los EE.UU.
Franklin Pierce (1804-1869): "Cada pedazo de esta tierra es sagrado para mi pueblo. Cada rama brillante de un pino, cada puñado de arena de las playas [... y el zumbar de los insectos son sagrados en la memoria y vida de mi pueblo" (López, s. f.). De esta manera, la ecosacralidad, pudiendo convertirse en ecosacrología, queda como materia pendiente para próximas reflexiones en las cuales la diversidad de religiosidades y espiritualidades deben, imperiosamente, posicionarse de forma sistemática en el concierto de incidencias, a favor de la vida, de carácter socio, político, religiosas y espirituales a nivel global.

\section{Conclusión}

A lo largo del artículo, se han propuesto tres neologismos como ejes centrales. Mediante esta propuesta se construye la sinergia narrativa entre todas las demás reflexiones: Necroecoteología, subjetividad instrumental y ecosacralidad (ecosacrología). La persistente disociación de la reflexión y análisis ecoteológica del escenario político local, regional y mundial exige poner en evidencia la interrelación filosófica, política e ideológica de una comprensión de la religiosidad y espiritualidad instrumentalizada por la atomización analítica de disciplinas como las ciencias sociales, políticas, jurídicas y económicas. 
En una primera parte, la necroecoteología es asumida desde su matriz filosófica. La teología se impregnó de matices helénicos (dualidad, jerarquización, relativización) los cuales fueron canonizados con incuestionable infalibilidad. La ordenanza divina, "dominar" la naturaleza, y en nombre de la ordenanza "aprovechando los frutos de ella" (Descartes) fueron la base de la instrumentalización de la fe y razón con fines extractivistas y segregacionistas. La necroecoteología inspirada en la necropolítica de Mbembe, agrega elementos como fe, racionalidad y subjetividad instrumental y ecosacralidad, entre otras, como claves metodológicas de aproximación al urgente tema de la destrucción de la casa común. En esta primera parte, la asociación de la base ideológico-religiosa de la necroecoteolgía con el fetiche, trabajado por Marx y otros, nos abre paso a la abstracción religiosa de una vigente matriz de control y dominio de corporeidades y territorialidades.

En la segunda parte, desde la perspectiva de la necroecoteología, y autores como Descartes, Marx. Weber, Horkheimer, Girard, Boff, Dussel, Santana y Tamayo, se propone cuatro variables de lectura e interpretación de la realidad humano-ambiental sin las cuales, en nuestra opinión, cualquier abstracción teológico-religiosa, sobre el problema de la crisis humano-ambiental, sería por un lado, especulación legitimadora del statu quo depredador y, por otro lado, un ejercicio de lectura e interpretación de la realidad desde una postura cercana al fundamentalismo literalista, acrítico y ahistórico, en claro desarrollo a nivel global. Cerrando este apartado, resalta en esta parte la propuesta de la subjetividad instrumental y su poder instrumentalizador sobre los sentimientos religiosos tanto desde la perspectiva de los pueblos invasores como de los invadidos; nadie se salva.

En la tercera parte, Marx trabaja el trasfondo mitológico del monoteísmo judeocristiano relacionado con el capitalismo y la percepción idolátrica del mismo desde la figura del fetiche. Como se sostuvo en el capítulo aludido, desde la labor desmitologizadora de Marx sobre tradiciones hermenéuticas judeocristianas enajenantes, como el mito del Génesis, se propone en la clave de lectura desde una inversión teológica de la tesis necroecoteologica. Clave que abre puertas a la visualización de lo que denominamos inversión teológica, figura hermenéutica que, por un lado, desmitologiza la narrativa de la creación y la ordenanza divina a trabajar como resultado del pecado original y explotar el mundo para usufrutuar sus recursos $\mathrm{y}$, por otro lado, se evidencia el costo del mito del progreso sobre la base del fetiche original: el fratricidio (Dussel). 
La cuarta parte, desde la necroecoteología y homo æeconomicus, se propone la lectura del ego cogito (Dussel) desde lo que denominamos trilogía del poder: Capital, mercado y mercancía/ dinero. En este apartado, se coloca en relieve la máxima teológica que señala la creación del ser humano a imagen y semejanza, según testimonios proféticos, de un Dios que toma posición por los débiles de la Tierra, construyendo paz desde la justicia. La trilogía de poder engendro al ser humano a su imagen y semejanza: homo religious-homo oeconomicus ensimismado en su autonomía con fines productivos.

La quinta parte enfatiza el terror como método necroecoteológico. Las evidencias de estos, macabros caminos, saltan a la vista en las actuales circunstancias de pandemia por la cual atravesamos; miles de vidas mueren diariamente debido a bloqueos de perfil económico, financiero y comercial aplicados por ejemplo a pueblos como Cuba y Venezuela. Medidas arbitrarias, en el plano político internacional, como las denominadas medidas coercitivas unilaterales, considerados violentos instrumentos jurídicos, en materia de derecho internacional y derechos humanos, son estructurados cual mecanismos punitivos, divino-humano, aplicados, por "fuerzas sobrehumanas", asistidas por leyes naturales, ubicadas sobre el bien y el mal. Medidas arbitrarias y terroríficas aplicadas, impunemente, sobre la nueva versión de los "pueblos bárbaros" de época del imperio romano.

Finalmente, contando con un sinnúmero de aportes ecuménicos, plurirreligiosos, sincréticos y agnósticos, en donde la vida, en todas sus manifestaciones, ha sido defendida, la ecosacralidad es el esfuerzo, no solo metodológico, propuesto en búsqueda de resignificación del sentido de la sacralidad de la vida. La inversión de valores, con el advenimiento del capitalismo depredador, sacramentó la trilogía de poder: Capital, mercado y mercancía/dinero; se atribuyó naturaleza confesional judeocristiana a una matriz de control profano de inspiración pagana: el fetiche. Por consiguiente, la ecosacralidad es la fuerza de reflexión, convivencialidad y alteridad, que surge de las entrañas del valor de la vida per se. $\mathrm{Y}$, a partir de esa revaloración y resignificación de la praxis liberadora, de toda enajenación y alienación humano-ambiental, la ecosacralidad se une a toda propuesta pro la trascendencia de parámetros monoteístas y politeístas procurando abarcar, de esta manera, la complejidad del misterio de la vida y la muerte desde una dimensión cíclica de orden/transición/desorden, destrucción/transición/creación y evolución/transición/revolución, desde la potencia del amor (eros) y no del odio (miseîn). 


\section{Referencias}

Alighieri, D. (1944). La divina comedia ( $3^{\mathrm{a}}$ ed.). Editora Sopena Argentina, S.R.L.

Baldó, M. (1993). La revolución industrial. Editorial Síntesis.

Betto. (2012, 17 de febrero). El nuevo fetiche. Biodiversidad LA.https://www.biodiversidadla.org/ Documentos/El_nuevo_fetiche

Bolívar, E. (2011). Crítica de la modernidad capitalista. Vicepresidencia del Estado Plurinacional de Bolivia.

Boff, L. (1978). Teología del cautiverio y la liberación. Ediciones Paulinas.

Boff, L. (1985). Jesucristo el liberador. Sal Terrae.

Boff, L. (2000). La dignidad de la tierra. Ecología, mundialización, espiritualidad. La emergencia de un nuevo paradigma. Editorial Trotta, S.A.

Boff, L. (2021a, 25 de abril). ¿Comer el mundo o salvaguardar el mundo? Koinonia. https://www. servicioskoinonia.org/boff/articulo.php?num=1022

Boff, L. (2021b, 19 de enero). ¿Es posible la fraternidad humana universal y con todas las criaturas? (I)Koinonia. https://www.servicioskoinonia.org/boff/articulo. php?num $=104$

Boff, L. (2021c, 8 de agosto). El caos de la pandemia esconde un nuevo orden en la tierra.

Koinonia. https://www.servicioskoinonia.org/boff/articulo. php?num=1034

Boff, L. (2021d, 15 de agosto). Marcos teóricos para entender la crisis actual. Leonardo Boff. https:// leonardoboff.org/2021/08/15/ marcos-teoricos-para-entender-la-crisis-actual/

Bloch, E. (2007). El principio esperanza (F. Serra, ed.). Editorial Trotta.

Cirlot, V. (1990). La estética de lo monstruoso en la Edad Media. Revista de literatura Medioeval, 2, 175-182. https://ebuah.uah. es/dspace/handle/10017/5088

Cone, J. (1973). Teología negra de la liberación. Carlos Lohlé., s.a.i.c.

Diez, G. (1955). San Bernardo. Obras completas. T, 11, Apología. B.A.C.

Dussel. E. (1974). Método para una filosofía de la liberación. Superación analéctica de la dialéctica hegeliana. Sígueme.

Dussel. E. (1977). Introducción a una filosofia de la liberación latinoamericana. Editorial Extemporaneos, S.A.

Dussel, E. (1978). Introducción a una filosofia de la liberación latinoamericana.Editorial Extemporáneos.

Dussel, E. (1978). Desintegración de la cristiandad colonial y 
liberación. Perspectiva latinoamericana. Ediciones Sígueme.

Dussel, E. (1983a). Historia general de la iglesia en América Latina. Introducción general a la historia de la iglesia en América Latina. Tomo I/1. Ediciones Sígueme.

Dussel, E. (1983b). Praxis latinoamericana y filosofia de la liberación. Editorial Nueva América.

Dussel, E. (1993). Las metáforas teológicas de Marx. Navarra (España): Editorial Verbo Divino.

Ellacuría, I. (1990). Utopía y profetismo. En Ellacuría, I y Sobrino, J. (eds.) Misterium Liberations. Conceptos fundamentales de la teología de la liberación. I. Editorial Trotta, y UCA Editores.

Foucault, M. (1989). El poder: Cuatro conferencias (A. Marquet, trad.). Universidad Autónoma Metropolitana.

Foucault, M. (2007). Nacimiento de la biopolitica: curso en el Collège de France, 1978-1979. Fondo de Cultura Económica. https:// www.ucursos.cl/facso/2017/1/ TS01023/1/material docente/ bajar?id_material $=17 \overline{00663}$

Foro de São Paulo. (2021, 7 de junio). Informe preliminar: violación de $\mathrm{DDHH}$ en Colombia. https://forodesaopaulo.org/informe-preliminar-violacion-de-ddhh-en-colombia/

Flórez, C. (2011). Descartes. Estudio introductorio de Cirilo
Flórez Miguel. Madrid: Gredos. www.researchgate.net/ publication/262460169_Descartes Rene Descartes Estudio_introductorio_de_Cirilo_ Florez_Miguel

Friedman, M. y Friedman, R. (1962). Libertad para elegir. University Chicago Press.

Galafassi, G. (2002). La teoría crítica de la Escuela de Frankfurt y la crisis de la idea de razón en la modernidad. En Contribuciones desde Coatepec. Núm. https://www.redalyc.org/ pdf/281/28100201.pdf

Galeano, E. (2004). Las venas abiertas de América Latina $\left(66^{\circ} \mathrm{Ed}\right.$.). Siglo XXI editores.

Gallardo, H. (1990). Fundamentos de formación política. Análisis de coyuntura. Chile: Editorial Literatura Alternativa, Departamento Ecuménico de Investigaciones (DEI).

Gallardo, H. (2010). Teoría crítica y derechos humanos. Una lectura latinoamericana, en REDHES Revista de Derechos Humanos y Estudios Sociales, 2(4), 57-89. http://www.derecho.uaslp.mx/ Documents/Revista\%20REDHES/N\%C3\%BAmero\%204/ Redhes4-03.pdf

Girad, R. (1989). La ruta antigua de los hombres perversos. Editorial Anagrama. 
Girad, R. (1995). La violencia y lo sagrado (J. Jordá, trad.). Editorial Anagrama.

Gudynas, E. (2003). Ecología, economía y ética del desarrollo sostenible. Quito: ILDIS.FES. https://ecuador.fes.de/fileadmin/ user_upload/pdf/0399.pdf

Gudynas. E. (2017). Sentir la Naturaleza. Errata, 18, 16-25. Rhttp:// accionyreaccion.com/wpcontent/uploads/2018/11/GudynasSentirNaturalezaErrataCol18b. pdf

Gutiérrez, G. (1975). Teología de la liberación. Perspectivas ( $7^{\mathrm{a}}$ ed.). Ediciones Sígueme.

Horkheimer, M. (1969). Crítica de la razón instrumental. SUR.

Horkheimer, M. y Adorno, T. (1969). Dialéctica del iluminismo. Sudamericana.

Hinkelammert, F. (1978). El dios mortal: lucifer y la bestia. La legitimación de la dominación en la tradición cristiana. En: Elsa Támez y Saúl Trinidad (eds.). Capitalismo: violencia y anti-vida. La opresión de las mayorías y la domesticación de los dioses. EDUCA.

Hinkelammert, F. (1984). Crítica a la razón utópica. Editorial DEI.

Hinkelammert, F. (1998a). El grito del sujeto. Del teatro-mundo del evangelio de Juan al perro-mundo de la Globalización. DEI.
Hinkelammert, F. (1998b). El proceso de globalización y los derechos humanos: la vuelta del sujeto, en Pasos, 79, pp. 23-28. http://coleccion.uca.edu.sv/franzhinkelammert/files/original/ $1 \mathrm{ddbce} 07 \mathrm{ac} 844 \mathrm{~b} 6 \mathrm{~b} 0 \mathrm{fb} 277 \mathrm{~b} 4 \mathrm{~d}-$ d3a0afd.pdf

Hinkelammert, F. (2003). El asalto al poder mundial y la violencia sagrada del imperio. DEI.

Illich, I. (1975). La Convivencialidad. Barral Editores.

Kerber, G. (2011). Ecoteología y cambio climático: Perspectivas ecuménicas. Cuadernos de Teología. Vol. XXX, 185-194. Presentación realizada en el ISEDET, Buenos Aires, en el Encuentro sobre Ecoteología (marzo, 2011).https://dialnet.unirioja.es/servlet/ articulo? codigo $=4102122$

Le Goff, J. (1977). I sogni nella cultura e nella psicología coUetiva dell'Occidente Medievale. En Tempo della chiesa e tempo del mercante e altri saggi sul lavoro e la cultura en el Medioevo. Ed. Eínaudi.

López de Gomara, F. (2009). La conquista de México. Linkgua ediciones. https://www.linkgua. com

López, 1. (s. f.). Carta del jefe Seattle al presidente de los Estados Unidos. https://ciudadseva. com/texto/carta-del-jefe-seattle-al-presidente-de-los-estadosunidos/ 
Marquínez, G. (2002). El amigo de Descartes que enseño en Santafé de Bogotá. Cuadernos salmatinos de filosofia, 29, 36-67. https://summa.upsa.es/pdf. vm?id=1148\&lang=es

Marx, C. y Engels, F. (2002). El capital. Tomo I: El proceso de producción del capital. Siglo XXI Editores. https://webs.ucm.es/ info/bas/es/marx-eng/capital1/

Marx, K (1867). El capital (2 $2^{\mathrm{a}}$ ed. $8^{\mathrm{a}}$ reimpr.). F.C.E.

Mariátegui, J.C. (2007). 7 Ensayos de interpretación de la realidad peruana $\left(3^{\mathrm{a}} \mathrm{Ed}\right.$.). Fundación $\mathrm{Bi}$ blioteca Ayacucho.

Mbembe, A. (2006). Necropolitica seguido de sobre el gobierno privado indirecto (E. Falomir Archambault, trad.). Editorial Melusina.

Quijano, A. (2000). Colonialidad del poder, eurocentrismo y América Latina. En Tanaka, M. (coord.). (2016), Antología del pensamiento crítico peruano contemporáneo. CLACSO.

Richard, P. y Torres, E. (1975). Cristianismo, lucha ideológica y racionalidad socialista. Ediciones Sígueme.

Rosillo, A. (2016). Repensar derechos humanos desde la liberación y la descolonialidad. Revista Direito e Práxis, 7, (13), 721749. https://www.redalyc.org/ pdf/3509/350944882023.pdf
Santa Ana, Julio de. (1991). La práctica económica como religión: crítica teológica a la economía política. DEI.

Santos, Boaventura de Sousa. (2003). Crítica de la razón indolente. Contra el desperdício de la experiencia. 1(18). Editorial Desclée de Brouwer.

Santos, Boaventura de Sousa. (2014). Justicia entre saberes: Epistemologías del Sur contra el epistemicidio. (R. Filella, trad.). Madrid: Ediciones Morata S.L.

Soberana Orden Templaría. (2020). San Bernardo de Claraval. https://sanbernardodeclaraval. wordpress.com/2020/08/06/ example-post-3/

Suess, P. (ed). (2002). La conquista espiritual de la América española. 200 documentos del siglo XVI. Abya-Yala. https://digitalrepository.unm.edu/cgi/viewcontent. cgi article $=1127 \&$ context $=a b-$ ya_yala

Tamayo. J.J. (2021, 26 de marzo). El cristoneofascismo, nueva religión. CIDAF-UCM. https://cidafucm.es/quienes-somos

Weber, M. (2004). La ética protestante y el espiritu del capitalismo (J. Chávez, trad.). Premiá editora de libros.

Xuaréz de Escobar, P. (s.f.). Carta de Pedro Xuárez de Escobar o.s.a a Felipe II, sobre el papel de los religiosos como padres, 
defensores y protectores de los indios (P. Suess, org.). La conquista espiritual de la América española. 200 documentos-Siglos XVI. (Original publicado el 1 de abril de 1579). https://digitalrepository.unm.edu/cgi/viewcontent.cgi? article $=1127 \&$ context=abya_y_la

Zenit. (16 de abril de 2008). Discurso de Benedicto XVI a George Busch en la Casa Blanca. Zenit. El mundo visto desde Roma. https://es.zenit.org/2008/04/16/ discurso-de-benedicto-xvi-ageorge-bush-en-la-casa-blanca/ 